\title{
Pengaruh Sikap pada Pelajaran Matematika dan Kebiasaan Belajar Matematika ditinjau dari Gaya Belajar terhadap Prestasi Belajar Matematika Siswa Kelas VIII SLTP Berorientasi Islam di Makassar
}

\author{
Ilham Minggi ${ }^{1, \text { a) }}$, Muhammad Dinar ${ }^{1, b)}$, dan Hasnainah ${ }^{1, \mathrm{c})}$ \\ ${ }^{1}$ Jurusan Matematika FMIPA Universitas Negeri Makassar \\ a) ilhamminggi@gmail.com \\ b) m.dinar@unm.ac.id \\ c) hasnainahaja@gmail.com
}

\begin{abstract}
Abstrak. Penelitian dilakukan untuk mengetahui pengaruh sikap pada pelajaran matematika dan kebiasaan belajar matematika ditinjau dari gaya belajar terhadap prestasi belajar siswa kelas VIII SLTP berorientasi islam di Makassar. Teknik pengumpulan data menggunakan instrumen angket sikap pada pelajaran matematika, angket kebiasaan belajar matematika, angket gaya belajar, dan tes prestasi belajar matematika. Hasil penelitian menunjukkan bahwa: (1) dari 80 responden, terdapat 27 siswa dengan gaya belajar visual, 14 siswa dengan gaya belajar auditori, dan 39 siswa dengan gaya belajar kinestetik,(2) sikap pada pelajaran matematika dan kebiasaan belajar matematika berada pada kategori tinggi untuk kelompok gaya belajar visual dan kinestetik, dan rendah untuk kelompok gaya belajar auditori (3) prestasi belajar berada pada kategori sedang untuk setiap kelompok gaya belajar, (4) sikap pada pelajaran matematika dan kebiasaan belajar matematika secara bersama-sama berpengaruh terhadap prestasi belajar matematika untuk setiap kelompok gaya belajar, (5) sikap pada pelajaran matematika berpengaruh positif terhadap prestasi belajar matematika untuk kelompok gaya belajar visual dan kinestetik, (6) kebiasaan belajar matematika berpengaruh positif terhadap prestasi belajar matematik untuk kelompok gaya belajar visual, (7) sikap pada pelajaran matematika berpengaruh secara tidak langsung terhadap prestasi belajar matematika melalui variabel kebiasaan belajar matematika untuk kelompok gaya belajar visual.
\end{abstract}

Kata Kunci: Sikap pada pelajaran matematika, Kebiasaan belajar matematika, Gaya belajar, Prestasi Belajar Matematika siswa.

\begin{abstract}
This research was conducted to determine the effect of attitudes on mathematics and mathematics learning habits in terms of learning style to Mathematics Learning Achievement Grade VIII SLTP Islamic oriented in Makassar. The technique of collecting data using instrument questionnaire of attitudes on mathematics, questionnaire of mathematics learning habits, questionnaire of learning style, and test result of mathematics learning. The result of the research shows that: (1) of 80 respondents, there were 27 students with visual learning style, 14 students with auditory learning style, and 39 students with kinesthetic learning style. (2) attitudes on mathematics and mathematics learning habits are in the high category for visual and kinesthetic learning style, and low category for auditory learning style, (3) mathematics learning achievement in the medium category for each learning style group, (4) attitudes on mathematics and mathematics learning habits jointly influence mathematics learning achievement for each learning style group, (5) attitudes on mathematics directly effect on mathematics learning achievement for visual and kinesthetic learning style group, (6) mathematics learning habits directly effect on mathematics learning achievement for visual learning style group, (7) attitudes on mathematics indirectly effect on mathematics learning achievement through variable mathematics learning habits for visual learning style group.
\end{abstract}

Keywords: Attitudes on mathematics, Mathematics learning habits, Learning style, Student's mathematics learning achievement. 


\section{PENDAHULUAN}

Keberhasilan suatu pembelajaran merupakan hal yang sangat di inginkan oleh setiap pendidik dalam melaksanakan tugasnya. Salah satu bentuk keberhasilan pembelajaran dapat dilihat dari prestasi belajar yang di capai oleh siswa. Prestasi belajar dipengaruhi oleh banyak faktor, faktorfaktor tersebut ada yang dari dalam diri siswa (internal) dan ada yang dari luar diri siswa (eksternal). Faktor internal pada diri siswa yang berpengaruh terhadap prestasi belajar siswa yaitu sikap pada pelajaran matematika, kebiasaan belajar matematika dan gaya belajar.

Sikap dalam belajar adalah kecenderungan prilaku seseorang saat mempelajari hal-hal yang bersifat akademik. Sikap dalam belajar matematika adalah perasaan senang atau tidak senang, perasaan setuju atau tidak setuju, perasaan suka atau tidak suka terhadap guru, tujuan materi dan tugas-tugas serta lainnya. Setiap siswa memiliki sikap yang berbeda-beda dalam menilai sesuatu hal. Ada yang memiliki sikap yang baik (positif) dan ada yang tidak baik (negatif). sikap sangat berkaitan dengan bagaimana reaksi terhadap sesuatu. Dalam hal ini, reaksi yang dimaksud adalah cara menerima, cara merespon, perasaan siswa terhadap pelajaran, dan cara menghargai. Cara yang dilakukan oleh siswa juga berbeda-beda. Artinya reaksi yang dikeluarkan siswa juga berbeda-beda. Siswa akan menyadari bagaimana cara mereaksi sesuatu dengan baik sehingga hasil yang diperolehnya juga baik.

Beberapa penelitian terkait mengkaji tentang sikap pada pelajaran matematika. Wahyuni (2016) meneliti tentang pengaruh sikap terhadap hasil belajar matematika siswa. Hasilnya menunjukkan bahwa terdapat pengaruh positif sikap terhadap hasil belajar matematika siswa.Hal senada juga dilakukan oleh Hartati (2015). Ia meneliti tentang pengaruh sikap pada pelajaran matematika terhadap hasil belajar siswa. Hasilnya menunjukkan bahwa ada pengaruh sikap pada pelajaran matematika terhadap hasil belajar siswa.

Selain sikap, kebiasaan belajar juga merupakan salah satu faktor (internal) yang mempengaruhi prestasi belajar. Kebiasaan yang efektif diperlukan oleh setiap individu dalam kegiatan belajarnya, karena sangat berpengaruh terhadap pemahaman dan hasil belajar yang akan diraih. Kebiasaan belajar sangat berkaitan dengan keterampilan belajar yang dimiliki seseorang. Keterampilan dalam belajar merupakan suatu cara yang dipakai untuk mendapat pengetahuan atau cara untuk menyelesaikan masalah. Keterampilan belajar yang baik akan membentuk kebiasaan belajar yang baik pula. Oleh karena itu, pembentukan kebiasaan belajar perlu dikembangkan. Kebiasaan belajar yang baik akan menjadi suatu cara yang melekat pada diri siswa, sehingga siswa akan melakukannya dengan senang dan tidak ada paksaan.

Beberapa penelitian terkait mengkaji tentang kebiasaan belajar matematika. Siagian (2015) meneliti tentang pengaruh kebiasaan belajar terhadap prestasi belajar matematika siswa. Hasilnya menunjukkan bahwa terdapat pengaruh kebiasaan belajar siswa terhadap prestasi belajar matematika siswa. Hal senada juga dilakukan oleh Alimuhajir (2015). Ia meneliti tentang pengaruh kebiasaan belajar terhadap hasil belajar matematika siswa. Hasilnya menunjukkan bahwa terdapat pengaruh yang signifikan antara kebiasaan belajar terhadap hasil belajar matematika siswa.

Selain sikap dan kebiasaan, gaya belajar juga merupakan salah satu faktor (internal) yang mempengaruhi prestasi belajar. Belajar pada umumnya merupakan aktivitas individu untuk mencari dan memperoleh pengetahuan, pengalaman maupun informasi melalui bahan belajar ataupun dari lingkungan. Untuk mendapatkan pengetahuan, seseorang menggunakan cara belajar yang berbeda-beda. Cara belajar yang digunakan oleh seseorang dalam belajar disebut juga dengan gaya belajar. Gaya belajar ditandai dengan cara konsisten siswa dalam merespon dan menggunakan stimulus yang diterimanya dalam aktivitas belajar. Gaya belajar dalam penelitian ini terdiri dari tipe visual, auditori, dan kinestetik.

Beberapa penelitian terkait mengkaji tentang gaya belajar. Azis (2018) meneliti tentang pengaruh gaya belajar terhadap prestasi belajar siswa. Hasilnya menunjukkan bahwa terdapat pengaruh positif antara gaya belajar terhadap prestasi belajar matematika siswa. Hal senada juga 
dilakukan oleh Wulan (2017). Ia meneliti tentang pengaruh gaya belajar terhadap prestasi belajar matematika. Hasilnya menunjukkan bahwa terdapat pengaruh gaya belajar terhadap prestasi belajar matematika siswa.

Pencapaian prestasi belajar dipengaruhi oleh beberapa faktor, penelitian ini berfokus pada faktor-faktor internal yang dapat terlibat dalam prestasi belajar siswa. Faktor-faktor internal tersebut diantaranya sikap pada pelajaran matematika, kebiasaan belajar matematika dan gaya belajar. Oleh karena itu, penelitian ini tentang Pengaruh Sikap pada Pelajaran Matematika dan Kebiasaan Belajar Matematika ditinjau dari Gaya Belajar terhadap Prestasi Belajar Matematika Siswa.

\section{KAJIAN TEORI}

\section{Sikap Pada Pelajaran Matematika}

Dalam usaha mencapai prestasi belajar apabila yang melakukan kegiatan belajar memiliki sikap yang baik (positif), dimungkinkan akan mencintai apa yang dikerjakan, sehingga pada akhirnya dapat mencapai tujuan pembelajaran secara maksimal. Menurut Thurtone (Wulan, 2017) sikap adalah suatu kecenderungan untuk berbuat secara positif atau negatif terhadap orang-orang, ideide, atau kejadian-kejadian. Sementara itu, Menurut LaPirre (Kurniawan, 2013) mendefinisikan sikap sebagai suatu perilaku, tendensi atau kesiapan antisipatif, predisposisi untuk menyesuaikan diri dari berbagai macam situasi yang terjadi dilingkungan sekitar, atau secara sederhana sikap merupakan suatu respon dari suatu keadaan timbul di lingkungan sekitar.

Menurut Krathwohl (Amri, 2016) sikap merupakan perilaku afektif yang terdiri atas lima tingkatan yaitu penerimaan (receiving) yaitu bagaimana cara ia memperhatikan materi yang diajarkan dengan baik, maka dapat dikatakan ia menerima pembelajaran yang sedang berlangsung, merespon (responding) yaitu merespon sesuatu yang di berikan oleh guru misalnya memberi sanggahan, tanggapan, dan menjawab dengan antusias pertanyaan yang di berikan, penentuan sikap (valuing) yaitu bagaimana perasaan siswa saat mengikuti pelajaran matematika dapat di ketahui dengan bagaimana cara ia mendiskusikan soal-soal matematika yang diberikan atau merasa senang jika di ajak untuk belajar matematika, pengorganisasian (organization) yaitu saat salah dalam mengerjakan soal, siswa dengan senang hati memperbaiki setiap kesalahankesalahan tersebut, dan karakterisasi (characterization) yaitu menghargai pendapat orang lain dalam suatu pembelajaran matematika.

Beberapa penelitian telah mengkaji tentang sikap pada pelajaran matematika. Wahyuni (2016) meneliti tentang pengaruh sikap terhadap hasil belajar matematika siswa. Subjek penelitian tersebut adalah siswa kelas X dan penelitian tersebut dilakukan pada salah satu sekolah kejuruan di Takalar. Hasilnya menunjukkan bahwa terdapat pengaruh positif sikap terhadap hasil belajar matematika siswa.

Hal senada juga dilakukan oleh Hartati (2015). Ia meneliti tentang pengaruh sikap pada pelajaran matematika terhadap hasil belajar siswa. Penelitian tersebut dilakukan pada salah satu sekolah kejuruan di Jagakarsa. Jumlah sampel yang diambil sebanyak 60 responden. Hasilnya menunjukkan bahwa ada pengaruh sikap pada pelajaran matematika terhadap hasil belajar siswa.

\section{Kebiasaan Belajar Matematika}

Kebiasan belajar merupakan hal yang penting dalam menentukan efektif tidaknya usaha belajar yang dilakukan. Kebiasaan belajar yang baik akan timbul dalam diri seseorang jika mempunyai niat untuk melakukannya. Niat yang di wujudkan dalam perbuatan berulang-ulang setiap hari sehingga menjadi suatu kebiasaan (Anugerah, 2012). Menurut Djaali (2007) menyatakan bahwa 
kebiasaan belajar matematika adalah cara belajar matematika yang biasa dilakukan secara berulang-ulang dan terus-menerus oleh siswa sehingga menjadi suatu kebiasaan setiap kali belajar, baik di dalam kelas maupun di luar kelas. Menurut Surachmand (Azis, 2018) mengemukakan lima dimensi yang berhubungan dengan kebiasaan belajar yang baik, yaitu kebiasaan mengikuti pelajaran, kebiasaan membaca buku, kebiasaan memantapkan pelajaran, kebiasaan menyiapkan karya tulis, dan kebiasaan menghadapi ujian.

Beberapa penelitian telah mengkaji tentang kebiasaan belajar matematika. Siagian (2015) dengan sampel penelian sebanyak 30 siswa dan penelian tersebut dilakukan d salah satu SMK di Cipayung. Ia meneliti tentang pengaruh kebiasaan belajar terhadap prestasi belajar matematika siswa. Hasilnya menunjukkan bahwa terdapat pengaruh kebiasaan belajar siswa terhadap prestasi belajar matematika siswa.

Hal senada juga dilakukan oleh Alimuhajir (2015). Ia meneliti tentang pengaruh kebiasaan belajar terhadap hasil belajar matematika siswa. . Subjek penelitian tersebut adalah siswa kelas hasil dan penelitian tersebut dilakukan pada salah satu sekolah menengah pertama di Lappariaja. Hasilnya menunjukkan bahwa terdapat pengaruh yang signifikan antara kebiasaan belajar terhadap hasil belajar matematika siswa.

\section{Gaya Belajar}

Belajar pada umumnya merupakan aktivitas individu untuk mencari dan memperoleh pengetahuan, pengalaman maupun informasi melalui bahan belajar ataupun dari lingkungan. Untuk mendapatkan pengetahuan, seseorang menggunakan cara belajar yang berbeda-beda. Cara belajar yang digunakan oleh seseorang dalam belajar disebut juga dengan gaya belajar. Menurut Prashnig (Wulan, 2017), kunci menuju keberhasilan dalam belajar adalah dengan mengetahui gaya belajar, cara individu untuk menyerap, mengatur dan mengolah informasi. Terdapat tiga jenis gaya belajar berdasar modalitas dalam memproses informasi (perceptual modality). Ken dan Dunn (Mu'arifah, 2011) mengidentifikasikan tiga gaya belajar, Visual yaitu belajar dengan cara melihat, Auditori yaitu belajar dengan cara mendengar, dan Kinestetik yaitu belajar dengan cara bergerak, bekerja, dan menyentuh.

Beberapa penelitian telah mengkaji tentang gaya belajar. Azis (2018) meneliti tentang pengaruh gaya belajar terhadap prestasi belajar siswa. Subjek penelitian tersebut adalah siswa kelas XI dan penelitian tersebut dilakukan pada salah satu sekolah menengah atas di Makassar. Jumlah sampel penelitian sebanyak 91 responden. Hasilnya menunjukkan bahwa terdapat pengaruh positif antara gaya belajar terhadap prestasi belajar matematika siswa.

Hal senada juga dilakukan oleh Wulan (2017). Ia meneliti tentang pengaruh gaya belajar terhadap prestasi belajar matematika. Subjek penelitian tersebut adalah siswa kelas VIII dan penelitian tersebut dilakukan pada salah satu sekolah menengah pertama di Yogyakarta. Jumlah sampel penelitian sebanyak 114 responden.Hasilnya menunjukkan bahwa terdapat pengaruh gaya belajar terhadap prestasi belajar matematika siswa.

\section{METODE PENELITIAN}

Jenis penelitian yang digunakan adalah penelitian kuantitatif dengan pendekatan Ex post facto. Ex post facto berarti sesudah sebuah fakta terjadi. Penelitian ini tidak memberikan perlakuan, melainkan mengungkapkan fakta yang terjadi secara alamiah dan sudah berlangsung, dan kemudian melihat kembali data-data untuk menentukan faktor-faktor yang mendahului. Penelitian ini dilaksanakan SLTP berorientasi islam di Makassar pada semester genap tahun ajaran 2018/2019. Variabel yang diselidiki dalam penelitian ini yaitu Sikap pada pelajaran matematika $\left(\mathrm{X}_{1}\right)$, Kebiasaan belajar matematika $\left(\mathrm{X}_{2}\right)$, Gaya Belajar $\left(\mathrm{X}_{3}\right)$, dan Prestasi belajar matematika $(\mathrm{Y})$. 


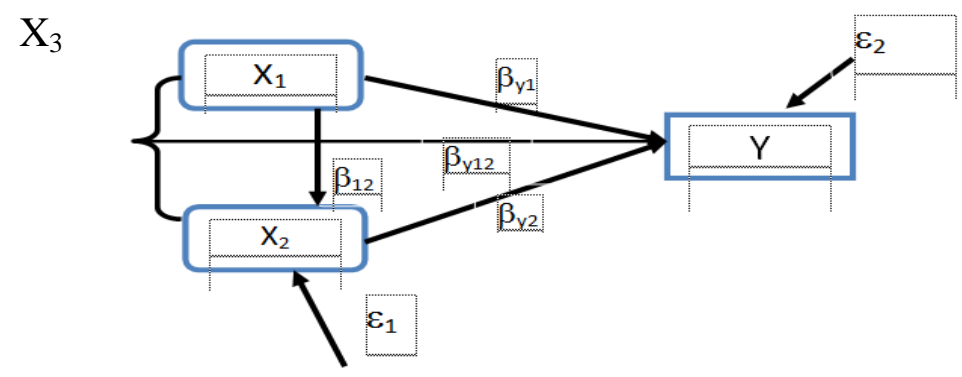

GAMBAR 1.Desain Penelitian untuk setiap gaya belajar

Pada Gambar 1, dapat dituliskan model persamaan strukturalnya sebagai berikut:

$$
\begin{aligned}
& X_{2}=\beta_{21} X_{1}+\varepsilon_{1} \\
& Y=\beta_{y 1} X_{1}+\beta_{y_{2}} X_{2}+\beta_{\mathrm{y} 2} X_{2}\left(\beta_{21} X_{1}\right)+\varepsilon_{2}
\end{aligned}
$$

Populasi dalam penelitian ini adalah siswa kelas VIII SLTP berorientasi islam di Makassar pada semester genap. Pengambilan sampel pada penelitian ini menggunakan teknik multistage random sampling, yaitu dengan mengambil dua sekolah secara acak kemudian mengambil 3 kelas secara acak dari kedua sekolah. Instrumen yang digunakan dalam penelitian ini ada 2, yaitu tes prestasi belajar matematika, kuisioner untuk mengukur sikap pada pelajaran matematika, kuisioner untuk mengukur kebiasaan belajar matematika, dan kuisioner untuk mengukur gaya belajar. Teknik pengumpulan data yang digunakan yaitu dengan tes dan Kuisioner.

TABEL 1.Kategorisasi Hasil Tes

\begin{tabular}{cc}
\hline Nilai Prestasi Belajar & Kategori \\
\hline $85-100$ & Sangat Tinggi \\
$75-84$ & Tinggi \\
$55-74$ & Sedang \\
$35-54$ & Rendah \\
$0-34$ & Sangat Rendah \\
\hline
\end{tabular}

Tabel 1 menunjukkan katgori skor hasil belajar siswa yang di kategorikan secara kuantitatif. Kriteria pengkategorian ini ditetapkan oleh Departemen Pendidikan dan Kebudayaan (Soevandi, 2016). Skor kategori sangat rendah dibawah 35 sedangkan skor kategori sangat tinggi adalah 85-100.

Data yang telah terkumpul kemudian diolah dengan menggunakan teknik analisis statistik, yaitu analisis statistik deskriptif dan analisis statistik inferensial. Analisis statistik deskriptif digunakan untuk mendeskripsikan karakteristik skor responden penelitian untuk masing-masing variabel meliputi mean, median, variansi, minumum, maksimum, dan kategorisasi. Analisis statistik inferensial digunakan untuk menguji hipotesis penelitian. Dalam penelitian ini digunakan path analysis (analisis jalur), yaitu bukan hanya untuk mengetahui apakah suatu variabel eksogen berpengaruh ke variabel endogen, melainkan juga untuk mengetahui besarnya pengaruh langsung dan tidak langsung. 


\section{HASIL DAN PEMBAHASAN}

\section{Hasil Analisis Statistika Deskriptif}

\section{Prestasi Belajar}

TABEL 2. Statistik Skor Prestasi Belajar Matematika

\begin{tabular}{lccc}
\hline \multicolumn{1}{c}{ Gaya Belajar } & Mean & Standar Deviasi & Variansi \\
\hline Visual & 66,67 & 7,44 & 55,38 \\
Auditori & 64 & 7,02 & 49,23 \\
Kinestetik & 64,82 & 5,67 & 32,15 \\
\hline
\end{tabular}

Berdasarkan Tabel 2, terlihat bahwa pada gaya belajar visual diperoleh nilai rata-rata, standar deviasi dan variansi tertinggi. Pada gaya belajar auditori diperoleh nilai terendah pada nilai ratarata dan variansi. Sedangkan pada gaya belajar kinestetik diperoleh nilai terendah pada standar deviasi.

Berdasarkan Tabel 3, untuk kelompok gaya belajar visual, terlihat bahwa tidak ada siswa yang berada pada kategori sangat rendah, rendah dan sangat tinggi. Akan tetapi terlihat lebih banyak siswa berada pada kategori sedang yaitu sebesar $85,19 \%$. Untuk kelompok gaya belajar auditori, terlihat bahwa tidak ada siswa yang berada pada kategori sangat tinggi dan kategori sangat rendah. Akan tetapi terlihat lebih banyak siswa berada pada kategori sedang yaitu sebesar $78,57 \%$. Sedangkan untuk kelompok gaya belajar kinestetik, terlihat bahwa tidak ada siswa yang berada pada kategori sangat tinggi, rendah dan sangat rendah. Akan tetapi terlihat lebih banyak pada kategori sedang yaitu sebesar $92,31 \%$.

TABEL 3. Distribusi Frekuensi dan Persentase Skor Prestasi Belajar Matematika

\begin{tabular}{|c|c|c|c|}
\hline Interval Nilai & Kategori & Frekuensi & Persentase (\%) \\
\hline \multicolumn{4}{|l|}{ Visual } \\
\hline $0-34$ & Sangat Rendah & 0 & $0 \%$ \\
\hline $35-54$ & Rendah & 0 & $0 \%$ \\
\hline $55-74$ & Sedang & 23 & $85,19 \%$ \\
\hline $75-84$ & Tinggi & 4 & $14,81 \%$ \\
\hline $85-100$ & Sangat Tinggi & 0 & $0 \%$ \\
\hline Jumlah & & 27 & 100 \\
\hline \multicolumn{4}{|l|}{ Auditori } \\
\hline $0-34$ & Sangat Rendah & 0 & $0 \%$ \\
\hline $35-54$ & Rendah & 1 & $7,14 \%$ \\
\hline $55-74$ & Sedang & 11 & $78,57 \%$ \\
\hline $75-84$ & Tinggi & 2 & $14,29 \%$ \\
\hline $85-100$ & Sangat Tinggi & 0 & $0 \%$ \\
\hline Jumlah & & 14 & 100 \\
\hline \multicolumn{4}{|l|}{ Kinestetik } \\
\hline $0-34$ & Sangat Rendah & 0 & $0 \%$ \\
\hline $35-54$ & Rendah & 0 & $0 \%$ \\
\hline $55-74$ & Sedang & 36 & $92,31 \%$ \\
\hline $75-84$ & Tinggi & 3 & $7,69 \%$ \\
\hline $85-100$ & Sangat Tinggi & 0 & $0 \%$ \\
\hline Jumlah & & 39 & 100 \\
\hline
\end{tabular}


Sikap pada pelajaran matematika

TABEL 4. Statistik Skor Sikap Pada Pelajaran Matematika visual

\begin{tabular}{lccc}
\hline \multicolumn{1}{c}{ Gaya Belajar } & Mean & Standar Deviasi & Variansi \\
\hline Visual & 57,88 & 10,61 & 112,64 \\
Auditori & 51,50 & 10,31 & 106,46 \\
Kinestetik & 57,11 & 7,16 & 51,29 \\
\hline
\end{tabular}

Berdasarkan Tabel 4, terlihat bahwa pada gaya belajar visual diperoleh nilai rata-rata, standar deviasi dan variansi tertinggi. Pada gaya belajar auditori diperoleh nilai terendah pada nilai ratarata. Sedangkan pada gaya belajar kinestetik diperoleh nilai terendah pada nilai standar deviasi dan variansi.

TABEL 5. Distribusi Frekuensi dan Persentase Sikap Pada Pelajaran Matematika visual

\begin{tabular}{lccc}
\hline \multicolumn{1}{c}{ Interval Nilai } & Kategori & Frekuensi & Persentase (\%) \\
\hline Visual & & & \\
\hline $20,000 \leq$ skor $<31,044$ & Sangat Rendah & 0 & $0 \%$ \\
$31,044 \leq$ skor $<53,209$ & Rendah & 11 & $40,74 \%$ \\
$53,209 \leq$ skor $<76,515$ & Tinggi & 14 & $51,85 \%$ \\
$76,515 \leq$ skor $<88,701$ & Sangat Tinggi & 2 & $7,41 \%$ \\
\hline Jumlah & & 27 & 100 \\
\hline Auditori & & 0 & $0 \%$ \\
\hline $20,000 \leq$ skor $<31,044$ & Sangat Rendah & 9 & $64,29 \%$ \\
$31,044 \leq$ skor $<53,209$ & Rendah & 5 & $35,71 \%$ \\
$53,209 \leq$ skor $<76,515$ & Tinggi & 0 & $0 \%$ \\
$76,515 \leq$ skor $<88,701$ & Sangat Tinggi & 14 & 100 \\
\hline Jumlah & & & $0 \%$ \\
\hline Kinestetik & & 0 & $23,08 \%$ \\
$20,000 \leq$ skor $<31,044$ & Sangat Rendah & 9 & $76,92 \%$ \\
$31,044 \leq$ skor $<53,209$ & Rendah & 30 & $0 \%$ \\
$53,209 \leq$ skor $<76,515$ & Tinggi & 0 & 100 \\
$76,515 \leq$ skor $<88,701$ & Sangat Tinggi & 39 & \\
\hline Jumlah & &
\end{tabular}

Berdasarkan Tabel 5, untuk kelompok gaya belajar visual, terlihat bahwa tidak ada siswa yang berada pada kategori sangat rendah dan lebih banyak pada kategori tinggi yaitu sebesar $51,85 \%$. Untuk kelompok gaya belajar auditori, terlihat bahwa tidak ada siswa yang berada pada kategori sangat tinggi dan kategori sangat rendah. Akan tetapi terlihat lebih banyak siswa berada pada kategori rendah yaitu sebesar 64,29\%. Sedangkan untuk kelompok gaya belajar kinestetik, terlihat bahwa tidak ada siswa yang berada pada kategori sangat tinggi dan kategori sangat rendah akan tetapi terlihat lebih banyak pada kategori tinggi yaitu sebesar 76,92\%.

\section{Kebiasaan belajar}

TABEL 6. Statistik Skor Kebiasaan Belajar Matematika

\begin{tabular}{lccc}
\hline \multicolumn{1}{c}{ Gaya Belajar } & Mean & Standar Deviasi & Variansi \\
\hline Visual & 77,27 & 8,09 & 65,5 \\
Auditori & 74,92 & 8,38 & 70,23 \\
Kinestetik & 78 & 7,48 & 55,98 \\
\hline
\end{tabular}

Berdasarkan Tabel 6, terlihat bahwa pada gaya belajar auditori diperoleh nilai tertinggi pada standar deviasi dan variansi dan nilai terendah pada rata-rata. Sedangkan pada gaya belajar kinestetik diperoleh nilai tertinggi pada rata-rata dan nilai terendah pada standar deviasi dan variansi. 
TABEL 7.Distribusi Frekuensi dan Persentase Skor Kebiasaan Belajar

\begin{tabular}{ccccc}
\hline $\begin{array}{c}\text { Gaya } \\
\text { Belajar }\end{array}$ & Interval Nilai & Kategori & Frekuensi & $\begin{array}{c}\text { Persentase } \\
(\mathbf{\%})\end{array}$ \\
\hline \multirow{4}{*}{ Visual } & $\mathbf{2 8 , 0 0 0} \leq$ skor $<\mathbf{4 3 , 5 0 6}$ & Sangat Rendah & 0 & $0 \%$ \\
& $\mathbf{4 3 , 5 0 6} \leq$ skor $<\mathbf{7 6 , 4 4 1}$ & Rendah & 17 & $62,96 \%$ \\
& $\mathbf{7 6 , 4 4 1} \leq$ skor $<\mathbf{1 1 3 , 0 2 5}$ & Tinggi & 10 & $37,04 \%$ \\
& $\mathbf{1 1 3 , 0 2 5} \leq$ skor $<\mathbf{1 3 2 , 1 8 2}$ & Sangat Tinggi & 0 & $0 \%$ \\
\cline { 2 - 5 } & $\mathbf{J u m l a h}$ & & 27 & 100 \\
\hline \multirow{4}{*}{ Auditori } & $\mathbf{2 8 , 0 0 0} \leq$ skor $<\mathbf{4 3 , 5 0 6}$ & Sangat Rendah & 0 & $0 \%$ \\
& $\mathbf{4 3 , 5 0 6} \leq$ skor $<\mathbf{7 6 , 4 4 1}$ & Rendah & 7 & $50 \%$ \\
& $\mathbf{7 6 , 4 4 1} \leq$ skor $<\mathbf{1 1 3 , 0 2 5}$ & Tinggi & 7 & $50 \%$ \\
& $\mathbf{1 1 3 , 0 2 5} \leq$ skor $<\mathbf{1 3 2 , 1 8 2}$ & Sangat Tinggi & 0 & $0 \%$ \\
\hline \multirow{4}{*}{ Kinestetik } & $\mathbf{J u m l a h}$ & & 14 & 100 \\
& $\mathbf{2 8 , 0 0 0} \leq$ skor $<\mathbf{4 3 , 5 0 6}$ & Sangat Rendah & 0 & $0 \%$ \\
& $\mathbf{4 3 , 5 0 6} \leq$ skor $<\mathbf{7 6 , 4 4 1} \leq$ skor $<\mathbf{1 1 3 , 0 2 5}$ & Rendah & 20 & $51,28 \%$ \\
& $\mathbf{1 1 3 , 0 2 5} \leq$ skor $<\mathbf{1 3 2 , 1 8 2}$ & Tinggi & 19 & $48,72 \%$ \\
\cline { 2 - 5 } & Sangat Tinggi & 0 & $0 \%$ \\
\hline
\end{tabular}

Berdasarkan Tabel 7, untuk kelompok gaya belajar visual, terlihat bahwa tidak ada siswa yang berada pada kategori sangat rendah dan sangat tinggi. Akan tetapi lebih banyak siswa berada pada kategori rendah yaitu sebesar $62,96 \%$. Untuk kelompok gaya belajar auditori, terlihat bahwa tidak ada siswa yang berada pada kategori sangat tinggi dan kategori sangat rendah. Sedangkan untuk kelompok gaya belajar kinestetik, terlihat bahwa tidak ada siswa yang berada pada kategori sangat tinggi dan kategori sangat rendah. Akan tetapi terlihat lebih banyak siswa berada pada kategori rendah yaitu sebesar $51,28 \%$.

Gaya belajar

TABEL 8. Statistik Skor Gaya Belajar Visual

\begin{tabular}{lccc}
\hline \multicolumn{1}{c}{ Gaya Belajar } & Mean & Standar Deviasi & Variansi \\
\hline Visual & 27,03 & 3,08 & 9,54 \\
Auditori & 25,81 & 2,34 & 5,49 \\
Kinestetik & 21,85 & 2,43 & 5,93 \\
\hline
\end{tabular}

Berdasarkan Tabel 8, terlihat bahwa pada gaya belajar visual diperoleh nilai rata-rata, standar deviasi dan variansi tertinggi. Pada gaya belajar auditori diperoleh nilai terendah pada standar deviasi dan variansi. Sedangkan pada gaya belajar kinestetik diperoleh nilai terendah pada nilai rata-rata.

Berdasarkan Tabel 9, untuk kelompok gaya belajar visual, terlihat bahwa tidak ada siswa yang berada pada kategori sangat rendah dan rendah. Akan tetapi lebih banyak siswa berada pada kategori tinggi yaitu sebesar $88,89 \%$. Untuk kelompok gaya belajar auditori, terlihat bahwa tidak ada siswa yang berada pada kategori sangat tinggi dan kategori sangat rendah. Akan tetapi lebih banyak siswa berada pada kategori tinggi yaitu sebesar 92,86\%. Sedangkan untuk kelompok gaya belajar kinestetik, terlihat bahwa tidak ada siswa yang berada pada kategori rendah dan kategori sangat rendah. Akan tetapi terlihat lebih banyak siswa berada pada kategori tinggi yaitu sebesar $74,36 \%$.

TABEL 9. Distribusi Frekuensi dan Persentase Skor Gaya Belajar

\begin{tabular}{cccc}
\hline \multicolumn{1}{c}{ Interval Nilai } & Kategori & Frekuensi & Persentase (\%) \\
\hline Visual & & & \\
\hline $7,000 \leq$ skor $<11,940$ & Sangat Rendah & 0 & $0 \%$ \\
$11,940 \leq$ skor $<21,504$ & Rendah & 0 & $0 \%$ \\
\hline
\end{tabular}


IMED 4(2) 2020, hal. $113-125$

\begin{tabular}{cccc}
\hline & & & \\
\hline $21,504 \leq$ skor $<30,851$ & Tinggi & 24 & $88,89 \%$ \\
$30,851 \leq$ skor $\leq 37,675$ & Sangat Tinggi & 3 & $11,11 \%$ \\
\hline Jumlah & & $\mathbf{2 7}$ & $\mathbf{1 0 0}$ \\
\hline Auditori & & 0 & $0 \%$ \\
\hline $8,000 \leq$ skor $<13,012$ & Sangat Rendah & 1 & $7,14 \%$ \\
$13,012 \leq$ skor $<22,366$ & Rendah & 13 & $92,86 \%$ \\
$22,366 \leq$ skor $<31,280$ & Tinggi & 0 & $0 \%$ \\
$31,280 \leq$ skor $<35,852$ & Sangat Tinggi & $\mathbf{1 4}$ & $\mathbf{1 0 0}$ \\
\hline Jumlah & & & $0 \%$ \\
\hline Kinestetik & & 0 & $0 \%$ \\
\hline $6,000 \leq$ skor $<9,515$ & Sangat Rendah & 0 & $74,36 \%$ \\
$9,515 \leq$ skor $<16,254$ & Rendah & 29 & $25,64 \%$ \\
$16,254 \leq \boldsymbol{s k o r}<23,219$ & Tinggi & 10 & $\mathbf{1 0 0}$ \\
$23,219 \leq$ skor $<26,961$ & Sangat Tinggi & $\mathbf{3 9}$ & \\
\hline Jumlah & &
\end{tabular}

\section{Hasil Analisis Statistik Inferensial}

\section{Uji Multikolinearitas}

Syarat uji multikoliearitas adalah nilai Tolerance lebih besar dari 0,1 dan nilai VIF setiap varibel untuk setiap model lebih kecil dari 10. Berdasarkan Tabel 10, diperoleh nilai Tolerance lebih dari 0,1 dan nilai VIP kurang dari 10 sehingga antar variabel bebas tidak terjadi gejala multikolinearitas untuk setiap kelompok gaya belajar.

TABEL 10. Hasil Uji Multikoleniaritas

\begin{tabular}{lcccc}
\hline Gaya Belajar & Model & Variabel & Tolarance & VIF \\
\hline Visual & 1 & Sikap pada pelajaran matematika & 1,000 & 1,000 \\
& 2 & Sikap pada pelajaran matematika & 0,569 & 1,758 \\
Auditori & 1 & Kebiasaan belajar matematika & 0,569 & 1,758 \\
& 2 & Sikap pada pelajaran matematika & 1,000 & 1,000 \\
& & Sikap pada pelajaran matematika & 0,460 & 2,173 \\
Kinestetik & 1 & Kebiasaan belajar matematika & 0,460 & 2,173 \\
& 2 & Sikap pada pelajaran matematika & 1,000 & 1,000 \\
& & Sikap pada pelajaran matematika & 1,543 & 1,842 \\
& & Kebiasaan belajar matematika & 1,543 & 1,842 \\
\hline
\end{tabular}

Uji Autokorelasi

TABEL 11. Hasil Uji Autokorelasi

\begin{tabular}{lccc}
\hline \multicolumn{1}{c}{ Gaya Belajar } & Model & Variabel & DW \\
\hline \multirow{3}{*}{ Visual } & 1 & Sikap Pada Pelajaran Matematika & 2,003 \\
& 2 & $\begin{array}{c}\text { Sikap Pada Pelajaran Matematika } \\
\text { Kebiasaan Belajar Matematika }\end{array}$ & 1,689 \\
Auditori & 1 & $\begin{array}{l}\text { Sikap Pada Pelajaran Matematika } \\
\text { Sikap Pada Pelajaran Matematika }\end{array}$ & 1,587 \\
& 2 & Kebiasaan Belajar Matematika & 1727 \\
Kinestetik & 1 & Sikap Pada Pelajaran Matematika & 1,735 \\
& 2 & Sikap Pada Pelajaran Matematika & 2,086 \\
& & Kebiasaan Belajar Matematika & \\
\hline
\end{tabular}


Syarat uji autokorelasi adalah dengan memenuhi syarat Durbin Watson yaitu du $<\mathrm{dw}<4-\mathrm{du}$. Berdasarkan Tabel 11 antara sikap pada pelajaran matematika dan kebiasaan belajar matematika setelah di akumulasikan untuk gaya belajar visual setiap model dengan nilai $n=27$ telah memenuhi uji syarat Durbin Watson. Untuk gaya belajar auditori setiap model dengan nilai $\mathrm{n}=14$ telah memenuhi uji syarat Durbin Watson. Dan untuk gaya belajar kinestetik setiap model dengan nilai $n=39$ telah memenuhi uji syarat Durbin Watson. Sehingga untuk setiap kelompok gaya belajar tidak terjadi gejala autokorelasi.

\section{Uji Heterokedasitas}

Berdasarkan Tabel 12, dengan melihat nilai signifikan dan alpha $=5 \%$. Terlihat bahwa nilai sig $>$ alpha untuk semua variabel independen yang artinya tidak ada satupun variabel independen yang signifikan secara statistik mempengaruhi variabel dependen. Jadi dapat disimpulkan bahwa model regresi tidak mengandung adanya heteroskedastisitas.

TABEL 12. Hasil Uji Heteroskedastisitas

\begin{tabular}{lccc}
\hline Gaya Belajar & Model & Variabel & Significancy \\
\hline \multirow{2}{*}{ Visual } & 1 & Sikap Pada Pelajaran Matematika & 0,092 \\
& 2 & Sikap Pada Pelajaran Matematika & 0,518 \\
\multirow{3}{*}{ Auditori } & 1 & Kebiasaan Belajar Matematika & 0,307 \\
& 2 & Sikap Pada Pelajaran Matematika & 0,863 \\
& 1 & Kebiasaan Pelajar Matematika & 0,754 \\
Kinestetik & 2 & Sikap Pada Pelajaran Matematika & 0,105 \\
& & Sikap Pada Pelajaran Matematika & 0,155 \\
& & Kebiasaan Belajar Matematika & 0,145 \\
\hline
\end{tabular}

Pengujian Hipotesis

TABEL 13. Hasil Uji Substruktural

\begin{tabular}{|c|c|c|c|c|}
\hline Gaya Belajar & $\begin{array}{c}\text { Variabel } \\
\text { Independen }\end{array}$ & $\begin{array}{c}\text { Standardized } \\
\text { Coefficient beta }\end{array}$ & $\begin{array}{c}\text { Sig. } \\
\text { coefficient }\end{array}$ & Sig. Anova \\
\hline \multicolumn{5}{|c|}{ Hasil uji substruktural pertama } \\
\hline Visual & $X_{1}$ & 0,657 & 0,000 & 0,000 \\
\hline Auditori & $X_{1}$ & 0,735 & 0,003 & 0,003 \\
\hline Kinestetik & $X_{1}$ & 0,676 & 0,000 & 0,000 \\
\hline \multicolumn{5}{|c|}{ Hasil uji substruktural kedua } \\
\hline \multirow[t]{2}{*}{ Visual } & $X_{1}$ & 0,417 & 0,006 & 0,000 \\
\hline & $X_{2}$ & 0,524 & 0,001 & \\
\hline \multirow[t]{2}{*}{ Auditori } & $X_{1}$ & 0,338 & 0,337 & 0,047 \\
\hline & $X_{2}$ & 0,362 & 0,305 & \\
\hline Kinestetik & $X_{1}$ & 0,640 & 0,000 & 0,000 \\
\hline
\end{tabular}

- Pengujian hipotesis 1

Sikap pada pelajaran matematika dan kebiasaan belajar matematika secara bersama-sama berpengaruh terhadap prestasi belajar matematika siswa

$$
\mathrm{H}_{0}: \beta_{\mathrm{Y} 1}=\beta_{\mathrm{Y} 2}=0 \text { lawan } \mathrm{H}_{1} \text { : paling sedikit ada satu } \beta_{\mathrm{Yi}} \neq 0, \mathrm{i}=1,2,3
$$

Berdasarkan hasil analisis pada Tabel 13, terlihat bahwa pada hasil uji substruktural kedua untuk gaya belajar visual, $X_{1}$ dan $X_{2}$ memiliki nilai signifikan anova sebesar 0,000 yang lebih kecil dari 0,05 sehingga $\mathrm{H}_{0}$ ditolak. Untuk gaya belajar auditori, $\mathrm{X}_{1}$ dan $\mathrm{X}_{2}$ memiliki nilai signifikan anova sebesar 0,047 yang lebih kecil dari 0,05 sehingga $\mathrm{H}_{0}$ ditolak. Dan untuk gaya 
belajar kinestetik, $X_{1}$ dan $X_{2}$ memiliki nilai signifikan anova sebesar 0,000 yang lebih kecil dari 0,05 sehingga $\mathrm{H}_{0}$ ditolak. Sehingga untuk ketiga kelompok gaya belajar, variabel sikap pada pelajaran matematika dan kebiasaan belajar matematika secara bersama-sama berpengaruh terhadap prestasi belajar matematika siswa.

- Pengujian hipotesis 2

Sikap pada pelajaran matematika berpengaruh secara positif terhadap Prestasi belajar matematika siswa

$$
\mathrm{H}_{0}: \beta_{\mathrm{Y} 1}=0 \text { lawan } \mathrm{H}_{1}: \beta_{\mathrm{Y} 1}>0
$$

Berdasarkan hasil analisis pada Tabel 13, terlihat bahwa pada hasil uji substruktural kedua untuk gaya belajar visual, $\mathrm{X}_{1}$ memiliki nilai signifikan sebesar 0,000 yang lebih kecil dari 0,05 sehingga $\mathrm{H}_{0}$ di tolak. Jika $\mathrm{H}_{0}$ ditolak maka variabel sikap pada pelajaran matematika berpengaruh secara positif terhadap prestasi belajar siswa. Untuk gaya belajar auditori, $\mathrm{X}_{1}$ memiliki nilai signifikan sebesar 0,337 yang lebih besar dari 0,05 sehingga $\mathrm{H}_{0}$ di terima. Jika $\mathrm{H}_{0}$ diterima maka variabel sikap pada pelajaran matematika tidak berpengaruh secara positif terhadap prestasi belajar siswa. Dan untuk gaya belajar kinestetik, $\mathrm{X}_{1}$ memiliki nilai signifikan sebesar 0,000 yang lebih kecil dari 0,05 sehingga $\mathrm{H}_{0}$ di tolak. Jika $\mathrm{H}_{0}$ ditolak maka variabel sikap pada pelajaran matematika berpengaruh secara positif terhadap prestasi belajar siswa. Dengan demikian, dari ketiga kelompok gaya belajar, hanya kelompok gaya belajar visual dan kinestetik yang berpengaruh positif terhadap prestasi belajar matematika siswa..

- Pengujian hipotesis 3

Kebiasaan belajar matematika berpengaruh secara positif terhadap Prestasi belajar matematika siswa

$$
\mathrm{H}_{0}: \beta_{\mathrm{Y} 2}=0 \text { lawan } \mathrm{H}_{1}: \beta_{\mathrm{Y} 2}>0
$$

Berdasarkan hasil analisis pada Tabel 13, terlihat bahwa pada hasil uji substruktural kedua untuk gaya belajar visual, $\mathrm{X}_{2}$ memiliki nilai signifikan sebesar 0,001 yang lebih kecil dari 0,05 sehingga $\mathrm{H}_{0}$ di tolak. Jika $\mathrm{H}_{0}$ ditolak maka variabel kebiasaan belajar matematika tidak berpengaruh secara positif terhadap prestasi belajar siswa. Untuk gaya belajar auditori, $\mathrm{X}_{2}$ memiliki nilai signifikan sebesar 0,305 yang lebih besar dari 0,05 sehingga $\mathrm{H}_{0}$ di terima. Jika $\mathrm{H}_{0}$ diterima maka variabel kebiasaan belajar matematika berpengaruh secara positif terhadap prestasi belajar siswa. Dan untuk gaya belajar kinestetik, $\mathrm{X}_{2}$ memiliki nilai signifikan sebesar 0,563 yang lebih besar dari 0,05 sehingga $\mathrm{H}_{0}$ di terima. Jika $\mathrm{H}_{0}$ diterima maka variabel kebiasaan belajar matematika tidak berpengaruh secara positif terhadap prestasi belajar siswa. Dengan demikian, dari ketiga kelompok gaya belajar, hanya kelompok gaya belajar visual yang berpengaruh positif terhadap prestasi belajar matematika siswa..

- Pengujian hipotesis 4

Sikap pada pelajaran matematika berpengaruh terhadap Prestasi belajar matematika melalui variabel kebiasaan belajar matematika siswa

$$
\mathrm{H}_{0}: \beta_{31} \times \beta_{\mathrm{Y} 3}=0 \text { lawan } \mathrm{H}_{1}: \beta_{31} \times \beta_{\mathrm{Y} 3}>0
$$

Berdasarkan hasil analisis pada Tabel 13, terlihat bahwa pada hasil uji substruktural pertama untuk gaya belajar visual, $\mathrm{X}_{1}$ memiliki nilai signifikan sebesar 0,000 yang lebih kecil dari 0,05 , yang artinya variabel sikap pada pelajaran matematika berpengaruh secara siginifkan terhadap kebiasaan belajar matematika. Karena sikap pada pelajaran matematika berpengaruh terhadap kebiasaan belajar matematika, maka berdasarkan hasil pengujian hipotesis $3 \mathrm{H}_{0}$ ditolak. Dengan demikian variabel sikap pada pelajaran matematika berpengaruh terhadap prestasi belajar melalui variabel kebiasaan belajar matematika siswa.

Untuk gaya belajar auditori, $\mathrm{X}_{1}$ memiliki nilai signifikan sebesar 0,003 yang lebih kecil dari 0,05 , yang artinya variabel sikap pada pelajaran matematika berpengaruh secara siginifkan terhadap kebiasaan belajar matematika. Karena sikap pada pelajaran matematika berpengaruh 
terhadap kebiasaan belajar matematika, maka berdasarkan hasil pengujian hipotesis $3 \mathrm{H}_{0}$ diterima. Dengan demikian variabel sikap pada pelajaran matematika tidak berpengaruh terhadap prestasi belajar melalui variabel kebiasaan belajar matematika siswa.

Untuk gaya belajar kinestetik, $\mathrm{X}_{1}$ memiliki nilai signifikan sebesar 0,000 yang lebih kecil dari 0,05 , yang artinya variabel sikap pada pelajaran matematika berpengaruh secara siginifkan terhadap kebiasaan belajar matematika. Karena sikap pada pelajaran matematika berpengaruh terhadap kebiasaan belajar matematika, maka berdasarkan hasil pengujian hipotesis $3 \mathrm{H}_{0}$ diterima. Dengan demikian variabel sikap pada pelajaran matematika tidak berpengaruh terhadap prestasi belajar melalui variabel kebiasaan belajar matematika siswa.

\section{KESIMPULAN}

Penelitian ini bertujuan untuk mengetahui pengaruh sikap pada pelajaran matematika dan kebiasaan belajar matematika ditinjau dari gaya belajar terhadap prestasi belajar siswa kelas VIII SLTP berorientasi islam di Makassar. Dari 80 responden terdapat 27 siswa yang cenderung dengan gaya belajar visual, 14 siswa yang cenderung dengan gaya belajar auditori dan 39 siswa yang cenderung dengan gaya belajar kinestetik. Adapun hasil yang diperoleh sebagai berikut:

1. Sikap pada pelajaran matematika dan kebiasaan belajar matematika secara bersama-sama berpengaruh terhadap prestasi belajar matematika siswa kelas VIII SLTP berorientasi islam di Makassar untuk setisp kelompok gaya belajar

2. Sikap pada pelajaran matematika berpengaruh positif terhadap prestasi belajar matematika siswa kelas VIII SLTP berorientasi islam di Makassar untuk kelompok gaya belajar visual dan kinestetik

3. Kebiasaan belajar matematika berpengaruh positif terhadap prestasi belajar matematika siswa kelas VIII SLTP berorientasi islam di Makassar untuk setisp kelompok gaya belajar visual

4. Sikap pada pelajaran matematika berpengaruh terhadap prestasi belajar matematika siswa kelas VIII SLTP berorientasi islam di Makassar melalui variabel kebiasaan belajar matematika untuk setiap kelompok gaya belajar visual

\section{DAFTAR PUSTAKA}

Alimuhajir. (2015). Pengaruh Perhatian Orang Tua, Kedisiplinan Dan Kebiasaan Belajar Matematika Terhadap Hasil Belajar Matematika Siswa Kelas Hasil SMP Negeri 1 Lappariaja. (Skripsi). Universitas Negeri Makassar, Makassar.

Amri. (2016). Pengembangan Instrumen Penilaian Ranah Afektif Pada Mata Pelajaran Biologi Di SMA. Jurnal Biotek. 4(1). 52-69.

Anugerah, A. S. (2012). Pengaruh Sikap Kreativitas Belajar Dan Kebiasaan Belajar Matematika Terhadap Hasil Belajar Matematika Pada Pokok Bahasan Lingkaran Dan Garis Singgung Lingkaran Siswa Kelas VIII SMP Negeri 4 Libureng. (Skripsi). Universitas Negeri Makassar, Makassar.

Azis, A. F. H. (2018). Pengaruh Kebiasaan Belajar, Gaya Belajar, Kepercayaan Diri Dan Kemandirian Belajar Terhadap Prestasi Belajar Matematika Siswa Kelas XI Mipa SMA Negeri 8 Makassar. (Skripsi). Universitas Negeri Makassar, Makassar.

Djaali. (2007). Psikologi Pendidikan. Jakarta : Bumi Aksara

Hartati, L. (2015). Pengaruh Gaya Belajar Dan Sikap Siswa Pada Pelajaran Matematika Terhadap Hasil Belajar Matematika. Jurnal Formatif, 3(3) . 224-235.

Kurniawan, A. C. (2013). Pengaruh Sikap Dan Kebiasaan Belajar Terhadap Prestasi Belajar Siswa Pada Mata Pelajaran Perbaikan Perawatan Kelistrikan Otomotif Program Studi 
Keahlian Teknik Mekanik Otomotif Kelas XI SMK PRI Sleman Tahun Ajaran 2012/2013. (Skripsi). Universitas Negeri Yogyakarta, Yogyakarta.

Mu'arifah, N. (2011). Pengaruh Interaksi Sosial, Tingkah Laku Dan Gaya Belajar Siswa Terhadap Hasil Belajar Matematika Siswa Kelas XII SMA Negeri 5 Makassar Pada Pokok Bahasan Barisan Dan Deret. (Skripsi). Universitas Negeri Makassar. Makassar.

Siagian, R. E. F. (2015). Pengaruh Minat Dan Kebiasaan Belajar Siswa Terhadap Prestasi Belajar Matematika. Jurnal Formatif 2(2). 122-131.

Soevandi, H. (2016). Pengaruh Modalitas Belajar Dan Strategi Kognitif Terhadap Prestasi Belajar Matematika Siswa Kelas VIII SMP Negeri 8 Makassar. (Skripsi). Universitas Negeri Makassar, Makassar.

Wahyuni. (2016). Pengaruh Sikap, KemampuanVerbal,Motivasi Berprestasi, Kemampuan Berfikir Divergen Dan Minat Belajar Terhadap Hasil Belajar Matematika siswa Kelas $X$ SMK Negeri 2 Takalar. (Skripsi). Universitas Negeri Makassar, Makassar.

Wulan, A. E. (2017). Pengaruh Gaya Belajar, Sikap Terhadap Pelajaran Matematika Dan Jenis Kelamin Bagi Prestasi Belajar Matematika siswa Kelas VIII SMP Maria Immaculata Marsudirini Yogyakarta Tahun Ajaran 2016/2017. (Skripsi). Universitas Sanata Dharma Yogyakarta, Yogyakarta. 